\title{
Care of the self in the daily living of nurses: an integrative review
}

\author{
O cuidado de si no cotidiano do enfermeiro: revisão integrativa \\ El cuidado de sí en el cotidiano del enfermero: una revisión integrativa
}

'Universidade Federal de São Paulo. São Paulo, São Paulo, Brazil.

Edson José da Silva Júnior'

ORCID: 0000-0002-7811-2032

Alexandre Pazetto Balsanelli'

ORCID: 0000-0003-3757-1061

Vanessa Ribeiro Neves ${ }^{1}$

ORCID: 0000-0002-2226-4723

How to cite this article:

Silva Jr EJ, Balsanelli AP, Neves VR. Care of the self in the daily living of nurses: an integrative review. Rev Bras Enferm. 2020;73(2):e20180668. doi: http://dx.doi.org/10.1590/0034-7167-2018-0668.

Corresponding Author:

Edson José da Silva Júnior

E-mail: nursedson@outlook.com

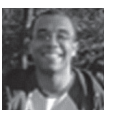

EDITOR IN CHIEF: Antonio José de Almeida Filho ASSOCIATE EDITOR: Italo Rodolfo Silva

Submission: 03-18-2018 Approval: 02-19-2019

\begin{abstract}
Objectives: to identify if nurses care for themselves and describe such practices. Methods: this is an integrative review of the literature published between 2006 and 2018 and indexed in the Literatura Latino-Americana e do Caribe em Ciências da Saúde, Medical Literature Analysis and Retrieval System Online and Web of Science databases. Results: the sample totaled 20 articles, grouped by content similarity in the thematic categories "limits and possibilities for the care of the self", "knowledge about practices on the care of the self" and "implications of care of the self in professional practice". Final considerations: the knowledge about techniques on caring for the self allows nurses to develop themselves personally and professionally. We suggest to managers and administrators a redirection of the nursing practice that contemplates the strengthening of the nurse as the manager of care and leader of the team, as well as the inclusion of the concept of care of the self in the curricula of undergraduate and graduate nursing courses.

Descriptors: Nursing; Care of the Self; Self-Care; Occupational Health; Nursing Human Resources.
\end{abstract}

\section{RESUMO}

Objetivos: identificar se os enfermeiros cuidam de si e descrever esse cuidado. Métodos: revisão integrativa da literatura publicada entre 2006 e 2018 e indexada nas bases de dados Literatura Latino-Americana e do Caribe em Ciências da Saúde, Medical Literature Analysis and Retrieval System Online e Web of Science. Resultados: a amostra totalizou 20 artigos, agrupados por similaridade de conteúdo nas categorias temáticas "limites e possibilidades para o cuidado de si", "conhecendo práticas para cuidar de si" e "implicações do cuidado de si na prática profissional". Considerações finais: o conhecimento das técnicas para o cuidado de si permite que o enfermeiro se desenvolva pessoal e profissionalmente. Sugere-se aos gestores um redirecionamento da prática que contemple o fortalecimento do enfermeiro como gestor do cuidado e líder da equipe, bem como a inclusão do cuidado de si nos currículos de graduação e pós-graduação.

Descritores: Enfermagem; Cuidado de Si; Autocuidado; Saúde do Trabalhador; Recursos Humanos de Enfermagem.

\section{RESUMEN}

Objetivos: identificar si los enfermeros cuidan de sí mismos y describir dicho cuidado. Métodos: revisión integrativa de la literatura publicada entre 2006 y 2018 e indexada en las bases de datos Literatura Latinoamericana y del Caribe en Ciencias de la Salud, Medical Literature Analysis and Retrieval System Online y Web of Science. Resultados: la muestra totalizó 20 artículos, agrupados por similitud de contenido en las categorías temáticas "Los límites y posibilidades en el cuidado de sí mismo", "Conociendo prácticas para cuidar de sí mismo" y "Las implicaciones del cuidado de sí mismo en la práctica profesional". Consideraciones finales: el conocimiento de las técnicas para el cuidado de sí le permite al enfermero el desarrollo personal y profesional. Se sugiere a los gestores una reorientación de la práctica que contemple el fortalecimiento del enfermero como gestor del cuidado y líder del equipo, así como la inclusión del cuidado de sí en los planes de estudios del grado y posgrado. Descriptores: Enfermería; Cuidado de Sí; Autocuidado; Salud Laboral; Personal de Enfermería. 


\section{INTRODUCTION}

The care for people has been considered the epistemological object of Nursing over its historical development. The nurse is the professional who cares for people from birth until death. But do nurses take care of themselves? Several studies have pointed stress, work overload and other problems that denote lack of care for the self among nurses ${ }^{(1-4)}$. Associated with these factors are the great pressure on the work environment, high ethical responsibility and low pay.

Care of the self cannot be considered something theoretical, dissociated from everyday life. This theme has been studied and reported since Ancient times, for example among ancient Greeks, who were concerned with the aspects that permeate the whole life process, from attention to their diet to performing physical activities and engaging in reflective moments, aiming at the maturing of the mind and the strengthening of the spirit ${ }^{(5)}$.

When nurses do not give due importance to these aspects, there may be direct interference in one's life and work. Some variables are related to this fact: the first one is the leadership that the nurse must perform, being a link between the nursing team and the whole multiprofessional team ${ }^{(6)}$. The mastering of self-awareness is critical for the development of leadership skills, because by performing care of the self, nurses will also be capable of knowing and caring for those under their leadership, consolidating professional actions according to the institutional philosophy, aiming at, among other things, patient safety. Moreover, as professionals who manage care, nurses must comprehend how certain emotions and actions can affect their life or the life of others, since empathy must be used to consolidate their caregiving $^{(7)}$. If a nurse does not know oneself, his/her values and does not understand what makes him/her happy or uncomfortable, such nurse can hardly be near individuals whose health is impaired.

Lack of care of the self may happen when the professional engages in caring for others while being distant from oneself, as if such care could be neutrally performed. This refers to the speech on health professionals as being free from diseases, compared to "ascetic priests" who use their instinct, their art, their abilities and even a kind of happiness of their own to fulfill all their tasks and to be whole and immune to diseases while performing their professional duties ${ }^{(8)}$.

Some literature reviews on this topic have already been made in Brazil $^{(9-11)}$; however, these reviews did not include international literature nor action proposals to make care of the self an effective practice. Seeking to fill these gaps, this study searched the literature for studies that answered the following research questions: do nurses take care of themselves? And how does this practice occur?

\section{OBJECTIVES}

To identify if nurses practice care of the self and describe such practices.

\section{METHODS}

This is an integrative literature review, a method that contributes to the deepening of the knowledge about the researched object, presenting the conclusions of the literature on a particular phenomenon and enabling the identification of knowledge gaps about a given phenomenon $^{(12)}$. The following steps were employed: definition of the research question, searching the databases, categorizing the studies, evaluating the studies included in the review, interpreting the results and synthesizing the knowledge produced ${ }^{(13)}$.

The guiding question established was: "what has been produced from 2006 to 2018 about nurses' care of the self?" This period was chosen because it would complement the studies already presented ${ }^{(9-11)}$ - conducted between 2006 and 2013 -, thus outlining a broader picture.

Eligible articles on the topic were considered as those available in English, Spanish or Portuguese and published between January 2006 to May 2018 in journals indexed in the Web of Science, Medical Literature Analysis and Retrieval System Online (Medline) - through the PubMed search engine - and Literatura Latino-Americana e do Caribe em Ciências da Sáude (Lilacs), accessed via the Brazilian version of Virtual Health Library (VHL). For the searches, the Boolean operators $A N D$ and $O R$ were combined with the descriptors self care, nurses and nursing - according to Medical Subject Heading (MeSH) terms -, and their corresponding words in Portuguese language: "cuidado de si", "autocuidado", "enfermeiro", "enfermeira" and "enfermagem", established by Health Sciences Descriptors (DeCS). In the Web of Science database the descriptor care of the self was also used. Searches were conducted in May 2018, excluding theses, dissertations, monographs, books and reviews of any kind.

In total, 1,164 articles were found, 860 in Lilacs, 299 in Medline and 5 in the Web of Science. These articles were selected according to the flowchart shown in Figure 1. To ensure the rigor of the selection of publications, all authors participated in this process. The abstracts of all 1,164 articles were read and of these, 1,113 were excluded due to not fitting the guiding question, 10 due to being duplicates (found in more than one consulted database), 8 due to not being fully accessible via Medline and 13 due to being meta-analyzes or reviews.

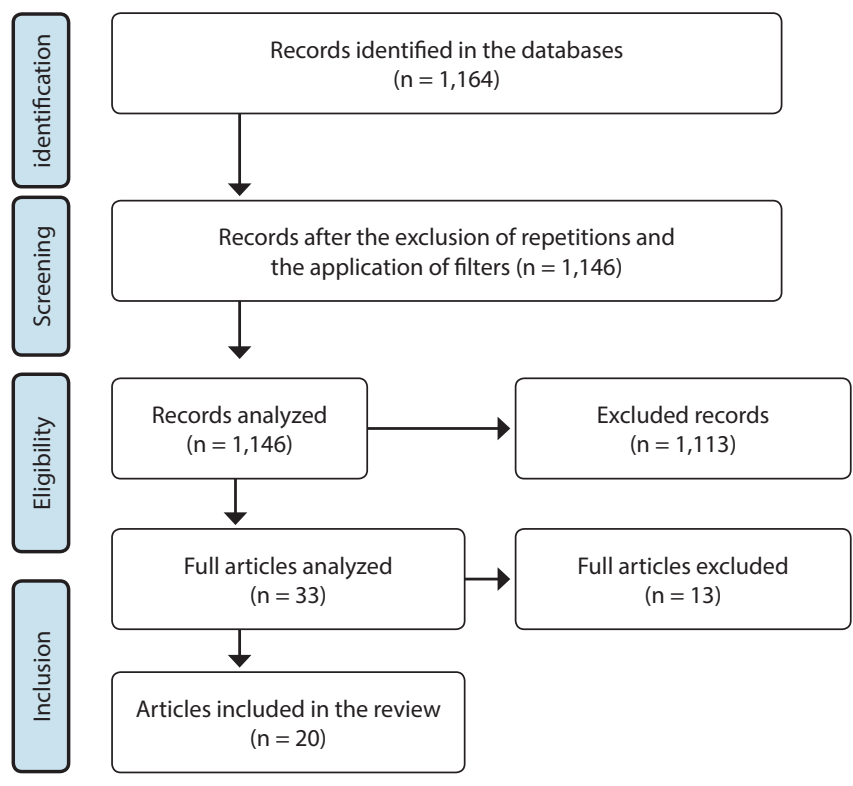

Figure 1 - Flowchart representing the search in the Lilacs, Medline and Web of Science databases 
Articles were classified according to the level of evidence, following the classification of Melnik and Fineout-Overholt ${ }^{(14)}$, which establishes that:

- Level 1: evidence from systematic review or meta-analysis.

- Level 2: evidence from at least one well-delineated, randomized controlled trial.

- Level 3: evidence from non-randomized well-delineated trials.

- Level 4: evidence from well-delineated cohort and casecontrol studies.

- Level 5: evidence from a systematic review of descriptive and qualitative studies.

- Level 6: evidence from a single descriptive or qualitative study.

- Level 7: evidence from an expert opinion.
Twenty articles were selected for evaluation in their entirety ${ }^{(15-34)}$. After characterization, which considered the variables title, objective and outcome of the articles, three categories were established, by content similarity: "limits and possibilities for the care of the self", "knowledge about practices on the care of the self" and "implications of care of the self in professional practice".

\section{RESULTS}

\section{Characterization of articles}

From the included studies, a chart was drawn up containing the characteristics of these publications and the categories they created.

Chart 1 - Characteristics and categorization of the selected articles

\begin{tabular}{|c|c|c|c|c|}
\hline Category & Title & Objective & Outcomes & Evidence \\
\hline \multirow{9}{*}{$\begin{array}{l}\text { Limits and } \\
\text { possibilities for the } \\
\text { care of the self }\end{array}$} & $\begin{array}{l}\text { Human relationships in the } \\
\text { work environment: lack of } \\
\text { self-care among nursing } \\
\text { professionals }{ }^{(15)}\end{array}$ & $\begin{array}{l}\text { To understand the meaning of } \\
\text { the (lack of) care of the self of } \\
\text { nursing professionals, as well as } \\
\text { the existing relations between } \\
\text { caring for others and care of } \\
\text { the self. }\end{array}$ & $\begin{array}{l}\text { The study showed a communication deficit } \\
\text { between the multiprofessional team, } \\
\text { generating dissatisfaction and competition } \\
\text { in the work environment. }\end{array}$ & 6 \\
\hline & $\begin{array}{l}\text { Taking care of yourself } \\
\text { to take care of the other: } \\
\text { reflections of nursing } \\
\text { professionals about self } \\
\text { care }^{(16)}\end{array}$ & $\begin{array}{l}\text { To analyze practices directed } \\
\text { to self-care of the nursing } \\
\text { professionals of an emergency } \\
\text { hospital. }\end{array}$ & $\begin{array}{l}\text { The practices of nursing professionals aimed } \\
\text { at self-care presented negative aspects. }\end{array}$ & 6 \\
\hline & $\begin{array}{l}\text { Meanings of themselves- } \\
\text { care of nursing professional } \\
\text { women in a emergency } \\
\text { unit }{ }^{(17)}\end{array}$ & $\begin{array}{l}\text { To understand the meaning } \\
\text { of the experience of women } \\
\text { nurses in the care of the self in } \\
\text { the daily care of an UPA. }\end{array}$ & $\begin{array}{l}\text { Actions on care of the self were found, but } \\
\text { the professionals are not always able to } \\
\text { put them into practice because of daily } \\
\text { occupations, which leads to a lack of time } \\
\text { for themselves. }\end{array}$ & 6 \\
\hline & $\begin{array}{l}\text { Gossip and occupation } \\
\text { in daily life of nursing } \\
\text { professional in itself and the } \\
\text { other care }^{(18)}\end{array}$ & $\begin{array}{l}\text { To comprehensively analyze } \\
\text { the care of the self and the care } \\
\text { for others and the meaning of } \\
\text { being a female nurse working } \\
\text { in a UPA. }\end{array}$ & $\begin{array}{l}\text { The meaning of being a female nursing } \\
\text { professional working in a UPA is based on } \\
\text { the dedication to the integral care for human } \\
\text { beings. However, such care only becomes full } \\
\text { when the being that cares is also taken care of. }\end{array}$ & 6 \\
\hline & $\begin{array}{l}\text { Nursing and self-care in the } \\
\text { world of psychiatric care }{ }^{(19)}\end{array}$ & $\begin{array}{l}\text { To understand the care of the } \\
\text { self of nursing professionals in } \\
\text { mental health. }\end{array}$ & $\begin{array}{l}\text { Care was found to be a stage of intense } \\
\text { interpersonal exchanges, agreements and } \\
\text { disagreements with each other, interfering } \\
\text { in the care for the other and in the care of } \\
\text { the self of each nursing professional. }\end{array}$ & 6 \\
\hline & $\begin{array}{l}\text { Nursing professional: } \\
\text { understanding self-care }\end{array}$ & $\begin{array}{l}\text { To understand the meaning of } \\
\text { (the lack of) care of the self for } \\
\text { nursing professionals. }\end{array}$ & $\begin{array}{l}\text { The neglect of care of the self seems to stem } \\
\text { from the lack of time to feed properly, to } \\
\text { engage in physical and aesthetic care of the } \\
\text { self, and also from giving up time for the self in } \\
\text { favor of work. }\end{array}$ & 6 \\
\hline & $\begin{array}{l}\text { Self-medication: showing } \\
\text { self carelessness by nursing } \\
\text { professionals }^{(21)}\end{array}$ & $\begin{array}{l}\text { By addressing the problem of } \\
\text { self-medication, to understand } \\
\text { the meaning of (the lack of) } \\
\text { care of the self for nursing } \\
\text { professionals. }\end{array}$ & $\begin{array}{l}\text { Self-medication reveals the lack of care of } \\
\text { the self that nursing professionals have for } \\
\text { themselves, who seek to minimize physical } \\
\text { or psychic symptoms without proper } \\
\text { medical advice. }\end{array}$ & 6 \\
\hline & $\begin{array}{l}\text { Care and its dimensions: } \\
\text { bases for the care of the self } \\
\text { of nursing professors }\end{array}$ & $\begin{array}{l}\text { To describe the conception of } \\
\text { nursing professors about care and } \\
\text { its dimensions in the perspective } \\
\text { of occupational health. }\end{array}$ & $\begin{array}{l}\text { Care is directed almost exclusively to the } \\
\text { other. There were no reports highlighting } \\
\text { the importance of care of the self. }\end{array}$ & 6 \\
\hline & $\begin{array}{l}\text { Nursing and self care: } \\
\text { perception of itself as a } \\
\text { existential body in the } \\
\text { world }^{(23)}\end{array}$ & $\begin{array}{l}\text { To understand the care of the } \\
\text { self of nursing professionals in } \\
\text { mental health. }\end{array}$ & $\begin{array}{l}\text { Care of the self happens to the extent that } \\
\text { the professional values himself/herself, } \\
\text { positioning himself/herself in the world as } \\
\text { a unique and existential body, interacting } \\
\text { with others in a dialogical way. }\end{array}$ & 6 \\
\hline
\end{tabular}




\begin{tabular}{|c|c|c|c|c|}
\hline Category & Title & Objective & Outcomes & Evidence \\
\hline \multirow{3}{*}{$\begin{array}{l}\text { Limits and } \\
\text { possibilities for the } \\
\text { care of the self }\end{array}$} & $\begin{array}{l}\text { Spirituality in self-care } \\
\text { for intensive care nursing } \\
\text { professionals }^{(24)}\end{array}$ & $\begin{array}{l}\text { To understand how spirituality } \\
\text { permeates the process of caring of } \\
\text { the self and the care for others in } \\
\text { the world of intensive care under } \\
\text { the eyes of nursing professionals. }\end{array}$ & $\begin{array}{l}\text { To be able to take care of the spirituality } \\
\text { of their patients, nurses must take care of } \\
\text { themselves through the continuous search } \\
\text { for harmony and integrity. }\end{array}$ & 6 \\
\hline & $\begin{array}{l}\text { Caring for the self, for } \\
\text { another, and for "us" within a } \\
\text { complexity perspective }\end{array}$ & $\begin{array}{l}\text { To conduct a reflective practice } \\
\text { with nursing professionals on the } \\
\text { meaning of care relationships that } \\
\text { permeate the work environment. }\end{array}$ & $\begin{array}{l}\text { There was an approximation of the } \\
\text { understanding of the interactions and } \\
\text { associations established between people } \\
\text { living in a complex world/scenario. }\end{array}$ & 6 \\
\hline & $\begin{array}{l}\text { Multiple relationships of } \\
\text { nursing care: the emergence } \\
\text { of care "of the us"(26) }\end{array}$ & $\begin{array}{l}\text { To understand the relationships } \\
\text { between care of the self, care for } \\
\text { the other and care for "us" in the } \\
\text { different dimensions of care. }\end{array}$ & $\begin{array}{l}\text { The care for "us" is an emerging theme, under } \\
\text { construction, that impels the concern with the } \\
\text { collective and refers to the understanding of } \\
\text { the multiple and infinite phenomena derived } \\
\text { from the constant movement between } \\
\text { subjects and their environment, modifying } \\
\text { relationship networks. }\end{array}$ & 6 \\
\hline \multirow{4}{*}{$\begin{array}{l}\text { Knowledge about } \\
\text { practices on the care } \\
\text { of the self }\end{array}$} & $\begin{array}{l}\text { Taking care of the caregiver } \\
\text { in the working setting: an } \\
\text { action proposal }\end{array}$ & $\begin{array}{l}\text { To stimulate the awareness of } \\
\text { the nursing team to care of the } \\
\text { self practices and to develop } \\
\text { actions to promote it within the } \\
\text { work environment. }\end{array}$ & $\begin{array}{l}\text { The developed actions and interactions } \\
\text { stimulated and enabled care of the self } \\
\text { inside and outside the work environment, } \\
\text { awakening in the professionals the awareness } \\
\text { of care of the self in work practices. }\end{array}$ & 6 \\
\hline & $\begin{array}{l}\text { Nurses as instruments of } \\
\text { healing: self-care practices } \\
\text { of nurses in a rural hospital } \\
\text { setting }^{(28)}\end{array}$ & $\begin{array}{l}\text { To understand self-care } \\
\text { practices and health promotion } \\
\text { behaviors of nurses in a rural } \\
\text { hospital and determine if there } \\
\text { is a need to develop a holistic } \\
\text { self-care program for the } \\
\text { hospital nursing staff. }\end{array}$ & $\begin{array}{l}\text { Most nursing professionals recognize } \\
\text { the importance of self-care. There is a } \\
\text { strong preference for fitness and nutrition } \\
\text { education programs over other types of } \\
\text { strategies. }\end{array}$ & 6 \\
\hline & $\begin{array}{l}\text { "Not just a theory": the } \\
\text { relationship between } \\
\text { Jin Shin Jyutsu }{ }^{\circledast} \text { self-care } \\
\text { training for nurses and stress, } \\
\text { physical health, emotional } \\
\text { health, and caring efficacy }{ }^{(29)}\end{array}$ & $\begin{array}{l}\text { To evaluate the effectiveness } \\
\text { of training nurses in Jin Shin } \\
\text { Jyutsu and to correlate such } \\
\text { training with the measurement } \\
\text { of personal and organizational } \\
\text { stress and patient care. }\end{array}$ & $\begin{array}{l}\text { Jin Shin Jyutsu is a valuable instrument for } \\
\text { nursing professionals due to decreasing } \\
\text { physical and emotional stress and improving } \\
\text { the effectiveness of care. Investing in Jin } \\
\text { Shin Jyutsu programs could increase the } \\
\text { quality of care provided. }\end{array}$ & 6 \\
\hline & $\begin{array}{l}\text { Nurses' lived experience of } \\
\text { Reiki for self-care }\end{array}$ & $\begin{array}{l}\text { To explore the experience of } \\
\text { nursing professionals who } \\
\text { practiced Reiki for self-care. }\end{array}$ & $\begin{array}{l}\text { The findings have direct implications for } \\
\text { nursing leaders and professors who seek to } \\
\text { explore innovative ways to recruit and retain } \\
\text { nurses in services and provide their well-being. }\end{array}$ & 6 \\
\hline \multirow{4}{*}{$\begin{array}{l}\text { Implications of } \\
\text { care of the self in } \\
\text { professional practice }\end{array}$} & $\begin{array}{l}\text { The importance of self-care } \\
\text { for nursing professionals }{ }^{(31)}\end{array}$ & $\begin{array}{l}\text { To identify the perception of } \\
\text { nursing professionals about the } \\
\text { care of the self }\end{array}$ & $\begin{array}{l}\text { Care of the self is important since the } \\
\text { actions developed for the maintenance of } \\
\text { this aspect improve the quality of nurses' } \\
\text { professional and personal life. }\end{array}$ & 6 \\
\hline & $\begin{array}{l}\text { Expanding self-awareness: } \\
\text { the caretaker looking him/ } \\
\text { herself in the mirror }{ }^{(32)}\end{array}$ & $\begin{array}{l}\text { To understand how nursing } \\
\text { caregivers perceive themselves } \\
\text { in expanding consciousness of } \\
\text { the self in caring for the other. }\end{array}$ & $\begin{array}{l}\text { It is believed that creating formal spaces } \\
\text { for the care of caregivers is necessary, } \\
\text { considering how they perceive themselves, } \\
\text { others and the world of care in hospitals. }\end{array}$ & 6 \\
\hline & $\begin{array}{l}\text { Helping nurses care for } \\
\text { self, family, and patients } \\
\text { through the nurses living fit } \\
\text { intervention }^{(33)}\end{array}$ & $\begin{array}{l}\text { To help nurses have an } \\
\text { improved quality of life via the } \\
\text { Nurses Living Fit (NLF) program. }\end{array}$ & $\begin{array}{l}\text { Nursing leaders must promote healthier } \\
\text { work environments, which can be done by } \\
\text { employing exercise and nutrition programs } \\
\text { like the NLF, which help nurses take better care } \\
\text { of themselves, their families and patients. }\end{array}$ & 6 \\
\hline & $\begin{array}{l}\text { Job satisfaction as self- } \\
\text { care within a restrictive } \\
\text { regulatory environment: } \\
\text { Nevada's study(34) }^{(34)}\end{array}$ & $\begin{array}{l}\text { To verify the characteristics of } \\
\text { nursing professionals and work } \\
\text { satisfaction. }\end{array}$ & $\begin{array}{l}\text { Data shows that work satisfaction helps } \\
\text { leaders improve patient care. }\end{array}$ & 6 \\
\hline
\end{tabular}

\section{DISCUSSION}

\section{Limits and possibilities for the care of the self}

Articles in this category ${ }^{(15-26)}$ showed that care of the self is fundamental and includes individual habits, customs, beliefs, and individual values. Self-neglect, observed as the main limitation for such care, can occur because the nurse's training focuses on the care for the other, not assigning enough importance to care for the self(35).

Associated with these factors, fragmentation, inadequate communication between team members, and lack of attribution of meaning to work are crucial to the disqualification of the care of the self ${ }^{(15-16)}$. When labor is fragmented and performed in an 
automatic manner, lacking associated reflexive practice, it shows a tendency of alienating ${ }^{(36)}$ professionals and compromising the perception on the need for care of the self.

Although professionals often realize the need for taking care of themselves, they cannot put it into practice. Day-to-day occupations drain the time that nurses could dedicate to themselves, so taking care of oneself takes second place and is even forgotten at times ${ }^{(17-19)}$.

The neglect of care of the self seems to stem from the lack of time to feed properly and to care of physical and aesthetic aspects, and from the need to give up time for oneself in favor of work ${ }^{(20)}$. Many professionals have more than one employment relationship, which reduces free time and impairs the care of the self. The lack of time, which can be interpreted as the lack of priority for the self, has a great possibility of causing stress and other psychic disorders. Moreover, the lack of adequate rest, coupled with the professional's exposure to adverse labor market conditions can lead to chronic pain, agitation, insomnia, anxiety and, consequently, self-medication ${ }^{(20)}$.

The indiscriminate use of medications to minimize physical or psychic symptoms reveals carelessness for the self and increases health risks ${ }^{(21)}$. Many professionals already suffer from psychological distress, but mainly use anxiolytic and analgesic drugs to mask the symptomatology and continue to perform their daily activities ${ }^{(37)}$.

Furthermore, other limiting factors to the care of the self were described by nurses: inadequate working hours, excessive bureaucracy, low pay, submission, impotence, competitiveness and incompatibility between work, family and leisure ${ }^{(22)}$.

The attribution of importance to the care of the self occurs as the individual values himself/herself, facing the world as his/ her own existential body, engaging in dialogical relationships with others ${ }^{(23)}$. The establishment of a support network among professionals was presented as a possibility for taking care of the self, contemplating and favoring communication and supportive care, including sensitivity, empathy and cooperation in situations of suffering, stress and helplessness in the work environment ${ }^{(24-26)}$.

Spirituality, self-knowledge and self-esteem are considered facilitating factors for the care of the self among nurses ${ }^{(23-24)}$. The search for inner development requires the desire to evolve and improve as a human being to achieve personal, professional, economic and social fulfillment ${ }^{(38)}$.

\section{Knowledge about practices on the care of the self}

Knowledge about care of the self is still incipient in the speech of professionals who care for other peoples' health. This may occur because health practices are still strongly anchored in the biomedical model and by organizational interferences in the work environment, so that nurses do not identify the need to take care of themselves so they can effectively take care of other people ${ }^{(39)}$.

Awareness about care of the self can be fostered in the nursing team within the work environment by encouraging professionals and the flexibility of managers. An action proposal developed in the South region of Brazil sought raise awareness about care of the self on the nursing team of an intensive care unit by proposing different activities such as stretching, group activities and relaxation activities. The proposal had a positive return, since professionals reported feeling cared for and valued, getting to know each other better and practicing caring actions for themselves ${ }^{(27)}$. From this analysis we can argue that practices on care of the self can and must be incorporated into nurses' daily work ${ }^{(40)}$. Such awareness will lead to excellent care practices with improved patient safety.

One study sought to understand self-care and health promotion practices among nurses at hospital in the United States to determine if there was a need to develop a holistic self-care program with these professionals ${ }^{(28)}$. The study showed that most nurses know the importance of caring of the self and prefer to participate in physical activity and nutritional education programs to achieve this goal. Thus, we can conclude that developing intervention proposals to improve the quality of life of this population is feasible.

Innovative practices were identified in hospitals in the United States to promote the care of the self among nurses, such as the use of complementary therapies ${ }^{(29-30)}$. Evaluating the effectiveness of training professionals in Jin Shin Jyutsu (an ancient healing art that uses hand contact on specific parts of the body to harmonize each person's life energy) and correlating training with the perception of personal and organizational stress and patient care, a study showed an increase in positive attitudes, gratitude, motivation, calmness, effective communication and significant reduction of anger, resentment, depression, stress symptoms and moral problems ${ }^{(29)}$. Nurses reported reduced muscle pain, insomnia, and headache. An increase in the effectiveness of care was also observed, occurring due to empathy, serenity, respect for differences, individualization, ability to minimize stress situations, planning for multiple needs and creativity in care.

Another study presented similar results by exploring the experience of nurses who practiced Reiki (a therapy that uses the touch to balance the body's energy centers) for self-care. This practice helped in the management of daily stress, in the strengthening of self-esteem and spirituality and in the connection with oneself, with others and with the whole ${ }^{(30)}$.

Studies of this category have shown that evidence-based intervention programs are needed to train nurses on the adoption of better lifestyles, and that managers must promote healthier work environments, which could improve the quality of care provided ${ }^{(41-42)}$

\section{Implications of care of the self in professional practice}

This category grouped the articles that evaluated the effects of caring of the self in the care of other people. Four studies were identified, two with a qualitative approach ${ }^{(31-32)}$ and two with a quantitative approach ${ }^{(33-34)}$.

The findings showed the relevance of care of the self, seeking to identify the nurses' perception of such care and to describe the actions taken to put it into effect, discussing its repercussions on health ${ }^{(31)}$. Care of the self was related to the actions undertaken by individual to improve and transform themselves by reflecting on their way of being and acting ${ }^{(43)}$ and it was found that care of the self is relevant for physical and mental health, and for work because the actions developed to maintain such care improve the quality of nurses' personal and professional lives.

Another critical issue regards the way nurses perceive themselves when expanding their self-awareness, taking care of the other ${ }^{(32)}$. The studies show that the self-perception of the professional as a being of sensitivity, aesthetic, possibilities, beliefs and values is an integral part of the expansion of self-awareness. The 
deepening of the relation of an individual with oneself can also improve the way one engages in relationships with others, since the correct conduct in relationships requires the full and effective care of the self. Such relationships must forgo the perspective of selfish individual interest, but search for individual improvement, overcoming limits and establishing goals.

The importance of ethics with regard to the patient is a crucial guiding axis of these studies, being understood as a product of effective practices on the care of the self. Criticism is fundamental but not only of others, especially of oneself, since the appropriate management of an individual's own life shall enable him/her to conduct and take good care of other people.

An intervention to help American nurses to improve their quality of life has been shown in another study that focused on the Nurses Living Fit (NLF) program, designed to reduce participants'body mass index (BMI) and to help, in addition to the nurses, their patients and family $^{(33)}$. Given the multidimensional way human beings are constituted, discussing the care with the body as a guiding axis for the care of the self is crucial. The study results showed that the participants had a significant reduction in BMl and waist circumference, as well as improvements in exercise frequency and their diet.

Another study addressed the demographic transition in the United States, specifically in the state of $\mathrm{Nevada}^{(34)}$. The large population growth associated with the lack of health care providers can generate an overload on the professionals available to take care of other people. Thus, the same individual may be subjected to having more than one job, being more subject to negative effects on health, such as illnesses and decreased satisfaction and productivity, which indicates the need to understand the importance of care of the self.

Practices on care of the self are thus understood as beneficial not only to the professional, but also to their patients and their families ${ }^{(44)}$.

\section{Study limitations}

The possible limitations of this study refer to the sample - since the articles included were those available online and free of charge, which may have led to the non-inclusion of some studies related to the theme - and the low level of evidence of the studies used according to the chosen classification ${ }^{(14)}$.

\section{Contributions to the field of nursing}

From the results found, managers and administrators are advised to change practices and anchor them in self-knowledge, considering the strengthening of nurses as care managers and immediate leaders of the care team. We also suggest the inclusion of the concept of care of the self in the curricula of undergraduate and graduate nursing programs.

\section{FINAL CONSIDERATIONS}

The knowledge of care of the self techniques involves the effective perception of the meaning of work and life, allowing nurses to develop personally and professionally. Caring of the self is caring for one's own soul, learning to live and having the possibility and duty of caring for oneself.

As limiting factors for the effective care of the self among nurses the demand for work, inadequate staffing, exhaustive working hours, unhealthy conditions were found, as well as bureaucracy, lack of autonomy and incompatibility between tasks, family and leisure.

The main differential of this literature review from others of the same theme was the inclusion of non-Brazilian studies. After the analysis, we found that, in Brazil, studies on the consolidation of practices on the care of the self, mainly in the work environment, are still incipient.

From the results found, managers and administrators are advised to change practices and anchor them in self-knowledge, considering the strengthening of nurses as care managers and immediate leaders of the care team. We also suggest the inclusion of the concept of care of the self in the curricula of undergraduate and graduate nursing programs.

\section{REFERENCES}

1. Padilha KG, Barbosa RL, Andolhe R, Oliveira EM, Ducci AJ, Bregalda RS, et al. Nursing workload, stress/burnout, satisfaction and incidents in a trauma intensive care units. Texto Contexto Enferm. 2017;26(3):e1720016. doi: 10.1590/0104-07072017001720016

2. Medeiros-Costa ME, Maciel RH, Rêgo DP, Lima LL, Silva MEP, Freitas JG. Occupational Burnout Syndrome in the nursing context: an integrative literature review. Rev Esc Enferm USP. 2017;51:e03235. doi: 10.1590/s1980-220x2016023403235

3. Martinez MC, Latorre MRDO, Fischer FM. Stressors influence work ability in different age groups of nursing professional: 2-year follow-up. Cienc Saude Colet. 2017;22(5):1589-600. doi: 10.1590/1413-81232017225.09682015

4. Azevedo BDS, Nery AA, Cardoso JP. Occupational stress and dissatisfaction with quality of work life in nursing. Texto Contexto Enferm. 2017;26(1):e3940015. doi: 10.1590/0104-07072017003940015

5. Ramos ED. Care of the self, the contemporary practices of the self and self-help speeches: a foucaultian reading [Internet]. 2016 [cited 2018 May 10];7(12):240-55. Available from: http://periodicos.pucminas.br/index.php/SapereAude/article/view/P.2177-6342.2016v7n13p240/9739

6. Carvalho AGF, Cunha ICKO, Balsanelli AP, Bernardes A. Authentic leadership and the personal and professional profile of nurses. Acta Paul Enferm. 2016;29(6):618-25. doi: 10.1590/1982-0194201600087

7. Silva IJ, Oliveira MFV, Silva SED, Polaro SHI, Radünz V, Santos EKA, et al. Care, self-care and caring for yourself: a paradigmatic understanding thought for nursing care. Rev Esc Enferm USP. 2009;43(3):690-5. doi: 10.1590/S0080-62342009000300028

8. Moraes MA, Monteiro SB. Vida, vivências, vivido na formação da enfermeira. Educ Soc Cult [Internet]. 2013 [cited 2018 May 05];38:185-202. Available from: https://www.fpce.up.pt/ciie/sites/default/files/12.dialogos_vivido.pdf 
9. Silva AA, Terra MG, Gonçalves MO, Souto VT. O cuidado de si entre profissionais de enfermagem: revisão das dissertações e teses brasileiras. Rev Bras Ciênc Saúde. 2014;18(4):346-52. doi: 10.4034/RBCS.2014.18.04.10

10. Oliveira RKM, Maia CAAS, Queiroz JC. Self-care in nursing: an integrative review. Rev Pesqui Cuid Fundam Online. 2015;7(1):2104-12. doi: 10.9789/2175-5361.2015.v7i1.2104-2112

11. Tomaschewski-Barlem JG, Piexak DR, Barlem ELD, Lunardi VL, Ramos AM. Scientific production of nursing about self-care: an integrative review. Rev Pesqui Cuid Fundam. 2016;8(3):4629-35. doi: 10.9789/2175-5361.2016.v8i3.4629-4635

12. Crossetti MGO. Integrative review of nursing research: scientific rigor required. Rev Gaúcha Enferm [Internet]. 2012 [cited 2018 May 2];33(2):8-13. Available from: http://seer.ufrgs.br/index.php/RevistaGauchadeEnfermagem/article/view/31430/19566

13. Paula CC, Padoin SMM, Galvão CM. Revisão integrativa como ferramenta para tomada de decisão na prática de saúde. In: Lacerda MR, Costenaro RGS, (Org.). Metodologias da pesquisa para a enfermagem e saúde: da teoria à prática. Porto Alegre: Moriá; 2016. p. 51-76.

14. Melnyk BM, Fineout-Overholt E. Evidence-based practice in nursing and health: a guide to best practice. Philadelphia: Wolters Kluwer; Lippincott Williams \& Wilkins Health; 2011.

15. Baggio MA. Relações humanas no ambiente de trabalho: o (des)cuidado de si do profissional de enfermagem. Rev Gaúcha Enferm [Internet]. 2007 [cited 2018 May 8];33(2):409-15. Available from: http://seer.ufrgs.br/index.php/RevistaGauchadeEnfermagem/article/ view/4695/2599

16. Targino THSJ, Silva PMC, Azevedo EB, Saraiva AM, Cordeiro RC, Ferreira Filha MO. Taking care of yourself to take care of the other: reflections of nursing professionals about self care. Rev Pesqui Cuid Fundam. 2013;5(4):440-8. doi: 10.9789/2175-5361.2013.v5i4.440-448

17. Elias EA, Souza IEO, Vieira LB. Meanings of themselves-care of nursing professional women in a emergency unit. Esc Anna Nery. 2014;18(3):415-20. doi: 10.5935/1414-8145.20140059

18. Salimena AMO, Elias EA, Souza IEO, Vieira LB. Falatório e ocupação no cotidiano das profissionais de enfermagem no cuidado de si e do outro. Rev Baiana Enferm. 2016;30(1):316-24. doi: 10.18471/rbe.v1i1.14393

19. Silva AA, Terra MG, Leite MT, Freitas FF, Xavier MS, Ely GZ. Nursing and self-care in the world of psychiatric care. Rev Pesqui Cuid Fundam. 2015;7(1):2011-20. doi: 10.9789/2175-5361.2015.v7i1.2011-2020

20. Baggio MA, Formaggio FM. Profissional de enfermagem: compreendendo o autocuidado. Rev Gaúcha Enferm [Internet]. 2007 [cited 2018 May 10];28(2):233-41. Available from: http://seer.ufrgs.br/index.php/RevistaGauchadeEnfermagem/article/view/3168/1739

21. Baggio MA, Formaggio FM. Automedicação: desvelando o descuidado de si dos profissionais de enfermagem. Rev Enferm UERJ [Internet]. 2009 [cited 2018 May 10];17(2):224-8. Available from: http://www.facenf.uerj.br/v17n2/v17n2a15.pdf

22. Soares RJO, Zeitoune RCG. O cuidado e suas dimensões: subsídios para o cuidar de si de docentes de enfermagem. Rev Pesqui Cuid Fundam. 2012;(Supl):41-44. doi: 10.9789/2175-5361.2012.v0i0.41-44

23. Silva AA, Terra MG, Motta MGC, Leite MT, Padoin SMM. Nursing and self care: perception of itself as a existential body in the world. Rev Enferm UERJ [Internet]. 2013 [cited 2018 May 10];21(3):366-70. Available from: http://www.e-publicacoes.uerj.br/index.php/ enfermagemuerj/article/view/7525

24. Dezorti LW, Crossetti MGO. Spirituality in self-care for intensive care nursing professionals. Rev Latino-Am Enfermagem. 2008;16(2):212-7. doi: 10.1590/S0104-11692008000200007

25. Baggio MA, Monticelli M, Erdmann AL. Cuidando de si, do outro e "do nós" na perspectiva da complexidade. Rev Bras Enferm. 2009;62(4):627-31. doi: 10.1590/S0034-71672009000400023

26. Baggio MA, Erdmann AL. Multiple relationships of nursing care: the emergence of care "of the us". Rev Latino-Am Enfermagem. 2010;18(5):895-902. doi: 10.1590/S0104-11692010000500009

27. Oliniski SR, Lacerda MR. Cuidando do cuidador no ambiente de trabalho: uma proposta de ação. Rev Bras Enferm. 2006;59(1):100-4. doi: $10.1590 /$ S0034-71672006000100019

28. Lubinska-Welch IL, Pearson T, Comer L, Metcalfe SE. Nurses as instruments of healing: self-care practices of nurses in a rural hospital setting. J Holist Nurs. 2016;34(3):221-8. doi: 10.1177/0898010115602994

29. Lamke D, Catlin A, Mason-Chadd M. "Not just a theory": the relationship between Jin Shin Jyutsu ${ }^{\varpi}$ self-care training for nurses and stress, physical health, emotional health, and caring efficacy. J Holist Nurs. 2014;32(4):278-89. doi: 10.1177/0898010114531906

30. Vitale A. Nurses' lived experience of Reiki for self-care. Holist Nurs Pract. 2009;23(3):129-47. doi: 10.1097/01.HNP.0000351369.99166.75

31. Ferreira ES, Souza MB, Souza NVDO, Pires AS. The importance of self-care for nursing professionals. Ciênc Cuid Saúde. 2015;14(1):978-85. doi: 10.4025/cienccuidsaude.v14i1.23360

32. Becker SG, Crossetti MGO. Ampliando a consciência do eu: o cuidador olhando-se no espelho. Rev Gaúcha Enferm [Internet]. 2007 [cited 2018 May 06];28(1):27-34. Available from: http://seer.ufrgs.br/index.php/RevistaGauchadeEnfermagem/article/view/4694/2615

33. Speroni KG, Williams DA, Seibert DJ, Gibbons MG, Earley C. Helping nurses care for self, family and patients through the nurses living fit intervention. Nurs Adm Q. 2013;37(4):286-94. doi: 10.1097/NAQ.0b013e3182a2f97f

34. Dunaway LL, Running A. Job satisfaction as self-care within a restrictive regulatory environment: Nevada's study. J Am Acad Nurse Pract. 2009;21(10):557-64. doi: 10.1111/j.1745-7599.2009.00446.x 
35. Shimizu HE, Couto DT, Merchan-Hamann E. Pleasure and suffering in intensive care unit nursing staff. Rev Latino-Am Enfermagem. 2011;19(3):565-72. doi: 10.1590/S0104-11692011000300016

36. Keshet Y, Popper-Giveon A. Work experiences of ethnic minority nurses: a qualitative study. Isr J Health Policy Res. 2016;5:18. doi: 10.1186/ s13584-016-0076-5

37. Pereira IF, Faria LC, Vianna RSM, Corrêa PDS, Freitas DA, Soares WD. Depression and use of medicines in nursing personnel. Arq Ciênc Saúde. 2017;24(1):70-4. doi: 10.17696/2318-3691.24.1.2017.544

38. Ponte PR, Koppel P. Cultivating mindfulness to enhance nursing practice. Am J Nurs. 2015;115(6):48-55. doi: 10.1097/01. NAJ.0000466321.46439.17

39. Campos LF, Melo MRAC. Assistência em enfermagem na perspectiva da clínica ampliada em unidade de terapia intensiva. Rev Gaúcha Enferm. 2011;32(1):189-93. doi: 10.1590/S1983-14472011000100025

40. Haley B, Heo S, Wright P, Barone C, Rettiganti MR, Anders M. Relationships among active listening, self-awareness, empathy, and patientcentered care in associate and baccalaureate degree nursing students. NursingPlus Open. 2017;3:11-6. doi: 10.1016/j.npls.2017.05.001

41. Dyess SM, Prestia AS, Smith MC. Support for caring and resiliency among successful nurse leaders. Nurs Adm Q. 2015;39(2):104-16. doi: 10.1097/NAQ.0000000000000101

42. Phiri LP, Draper CE, Lambert EV, Kolbe-Alexander TL. Nurses' lifestyle behaviours, health priorities and barriers to living a healthy lifestyle: a qualitative descriptive study. BMC Nurs. 2014;13(1):38. doi: 10.1186/s12912-014-0038-6

43. Clinton ME, Springler RA. Foucault's legacy for nursing: are we beneficiaries or intestate heirs? Nurs Philos. 2016;17(2):119-31. doi: 10.1111/ nup. 12113

44. Billington T. Promoting self-awareness through reflective practice. Br J Nurs. 2013;22(1):45. doi: 10.12968/bjon.2013.22.1.45 